\title{
An Andean ice-core record of a Middle Holocene mega-drought in North Africa and Asia
}

\author{
Mary E. DAVIS, ${ }^{1}$ Lonnie G. THOMPSON ${ }^{1,2}$ \\ ${ }^{1}$ Byrd Polar Research Center, The Ohio State University, 1090 Carmack Road, Columbus, OH 43210-1002, USA \\ E-mail: davis.3@osu.edu \\ ${ }^{2}$ Department of Geological Sciences, The Ohio State University, Columbus, 155 South Oval Mall, Columbus, \\ $\mathrm{OH}$ 43210-1398, USA
}

\begin{abstract}
An ice core from the Nevado Huascarán col in the Cordillera Blanca of northern Peru contains high-resolution time series of dust concentrations and size distributions since the end of the last glacial stage. A large dust peak, dated $\sim \mathbf{4 5 0 0}$ years ago, is contemporaneous with a widespread and prolonged drought that apparently extended from North Africa to eastern China, evidence of which occurs in historical, archeological and paleoclimatic records. This event may have been associated with several centuries of weak Asian/Indian/African monsoons, possibly linked with a protracted cooling in the North Atlantic. During the second half of the 20th century, high austral-summer dust concentrations in the Huascarán record are significantly correlated with atmospheric conditions, such as sea-level pressure and zonal wind velocities that are consistent with EI Niño-Southern Oscillation (ENSO) and positive North Atlantic Oscillation (NAO) indices, and with aridity in North Africa, southwest Asia and the Middle East. Therefore, the dominant submicron fraction of the dust may have been transported by more intense northeasterly trade winds from the African dry regions across the tropical Atlantic during a period of frequent and/or intense ENSO activity. The proposed ENSO conditions that may have been linked with drought in the monsoon region may also have contributed to aridity in tropical South America, including the Cordillera Blanca.
\end{abstract}

\section{INTRODUCTION}

Compared to the last glacial stage (LGS) and the subsequent deglaciation, the Holocene has been a period of relative climatic calm during which human populations and civilizations have flourished and expanded over the Earth. However, it has not been completely free of the kind of climatic disruptions that have had detrimental effects on even powerful societies. One such event, which was apparently a far-reaching period of aridity, occurred 4000-4500 years ago (4.0-4.5 kyr BP), and left its mark on a variety of archeological and geological records, including those from excavations in Syria (Weiss and others, 1993), lake levels in North Africa (Gasse, 1977; Servant and Servant-Vildary, 1980; Gillespie and others, 1983) and western China (Gasse and others, 1991), speoleothems in Israel (Bar-Matthews and others, 1999) and eastern China (Wang and others, 2005), marine cores from the Gulf of Oman (Cullen and others, 2000) and the Indus delta region (Staubwasser and others, 2003), peat deposits in Mongolia (Xiao and others, 2004), and an ice core from eastern equatorial Africa (Thompson and others, 2002). According to many of these records, the onset of the drought was abrupt (possibly within a decade), lasted for up to several centuries, then ended abruptly.

Although the majority of the documentation for this dry period comes from the Eastern Hemisphere, evidence for a similar abrupt climatic episode has been found in tropical South America. For example, deposits from Lake Titicaca on the border between Peru and Bolivia (Baker and others, 2001; Tapia and others, 2003) and from the Amazon fan (Maslin and Burns, 2000) show a Middle Holocene period of desiccation. Finally, an ice core from a high-altitude Andean tropical glacier contains a prominent dust event within the Holocene, with particle concentrations that are several orders of magnitude higher than all other levels since the end of the LGS (Thompson, 2000; Thompson and others, 2000). The timing and nature of the dust peak in this ice core, its possible linkages with the Asian/African climate, and the possible Middle Holocene climate forcings for such an event are discussed in this paper.

\section{ICE-CORE ANALYSIS}

In the austral winter of 1993 (June-August) a team from the Byrd Polar Research Center's (BPRC) Ice Core Paleoclimatology Research Group drilled two ice cores to bedrock on the col of Nevado Huascarán $\left(9^{\circ} 06^{\prime} \mathrm{S}, 77^{\circ} 36^{\prime} \mathrm{W}\right.$; $6050 \mathrm{ma.s.I}$.) in the Cordillera Blanca of northern Peru (Fig. 1). The first core (core 1, $160.4 \mathrm{~m}$ long) was cut into samples that were melted and bottled in the field, but the second (core 2, $166.1 \mathrm{~m}$ long) was returned frozen to BPRC for high-resolution analyses. This core was cut into three equivalent sets, each with 4476 samples, and analyzed for the ratios of ${ }^{18} \mathrm{O}$ to ${ }^{16} \mathrm{O}\left(\delta^{18} \mathrm{O}\right)$, mineral dust concentration and size distribution, and anion concentrations (chloride, nitrate and sulfate) analyses. Core 1, on the other hand, was analyzed only for $\delta^{18} \mathrm{O}$.

Above the firn/ice transition $(\sim 33.5 \mathrm{~m}$ below surface (mbs)) the three sets of samples were cut from the center of the core inside a class 100 clean bench in a laboratory freezer maintained at $-10^{\circ} \mathrm{C}$. The firn was handled using several pairs of pre-cleaned latex gloves, and the cut samples were placed in pre-cleaned polystyrene containers which were transported to a class 100 clean room where they were allowed to melt before analysis. Below the firn/ice transition the dust and anion samples were rinsed with Millipore reagent-grade deionized water to remove contaminants from the surface. The core was cut such that the 


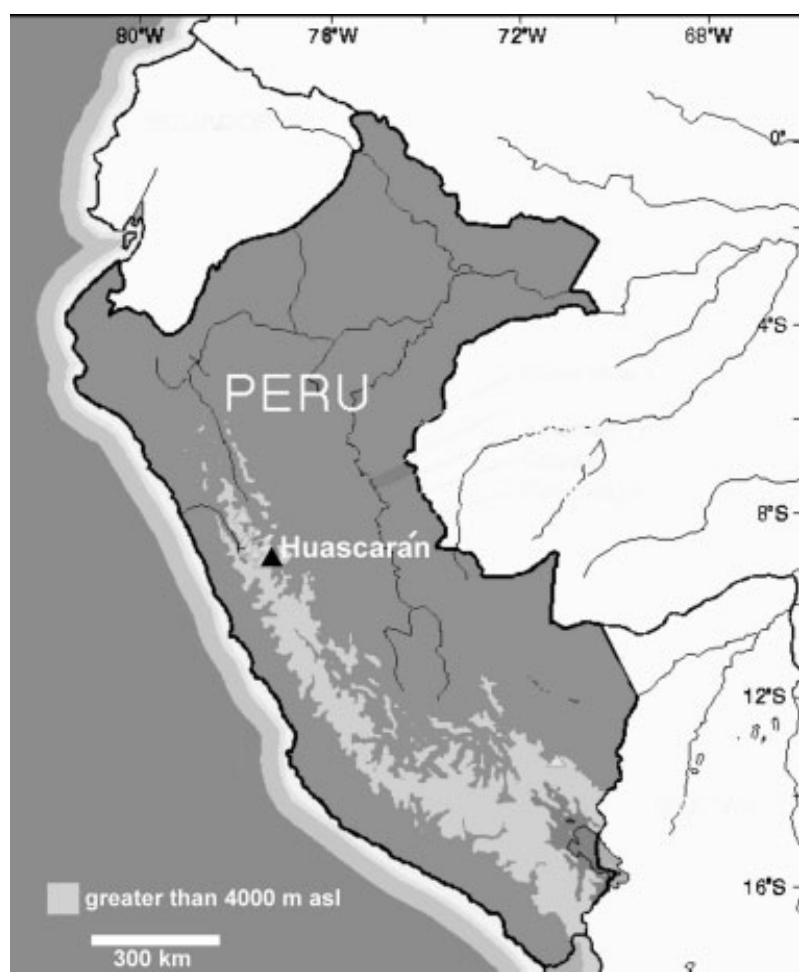

Fig. 1. Map of Peru depicting the Andes Mountains (areas above 4000 m a.s.l.) and the location of Nevado Huascarán.

sample lengths decreased from 17 to $6 \mathrm{~cm}$ in the top $55 \mathrm{~m}$, then from 5 to $3 \mathrm{~cm}$ in the interval $55-113 \mathrm{mbs}$, and finally to $\sim 2 \mathrm{~cm}$ at $113 \mathrm{mbs}$, which was the size at which they remained to the bottom of the core.

Dust concentrations and size distributions were measured using two Coulter Counters (Model TAII), one equipped with a $30 \mu \mathrm{m}$ aperture tube to count particles with diameters between 0.63 and $16 \mu \mathrm{m}$ in 14 size ranges, and the second equipped with a $100 \mu \mathrm{m}$ aperture tube to count particles with diameters between 2.0 and $40 \mu \mathrm{m}$, also in 14 size ranges. The two datasets were integrated and the total concentrations between 0.63 and $40 \mu \mathrm{m}$ were normalized to $1 \mathrm{~mL}$ of melted ice. A Finnigan MAT Delta $\mathrm{E}$ mass spectrometer was used for the analyses of $\delta^{18} \mathrm{O}$. The anion concentrations, which were analyzed with a Dionex Model 2010 ion chromatograph, were presented initially in Thompson and others (1995), but will not be discussed further here.

The $\delta^{18} \mathrm{O}$ and dust concentration data are plotted by depth ( $1 \mathrm{~m}$ averages) in Figure $2 \mathrm{a}$ and $\mathrm{b}$, respectively. One obvious feature in the $\delta^{18} \mathrm{O}$ profile is the $6.3 \%$ increase from $\sim 165.3 \mathrm{mbs}$ to $\sim 163 \mathrm{mbs}$, which is consistent with the Last Glacial Maximum to Early Holocene isotopic difference found in other ice cores of similar age (Thompson and others, 1998, table 2). The dust record shows that above $165 \mathrm{mbs}$ this core is relatively clean, with an average concentration of $\sim 15000$ particles per $\mathrm{mL}$. The exception is a large peak around 157.7 mbs (marked with an asterisk in Fig. 2b) with an average concentration of $\sim 82000$ particles per $\mathrm{mL}$.

\section{TIMESCALE RECONSTRUCTION}

Since the 1 year snow accumulation between 1992 and 1993 was $3.30 \mathrm{~m}$ (1.74 m ice equivalent), and the 20thcentury net accumulation rate, or net balance, averaged

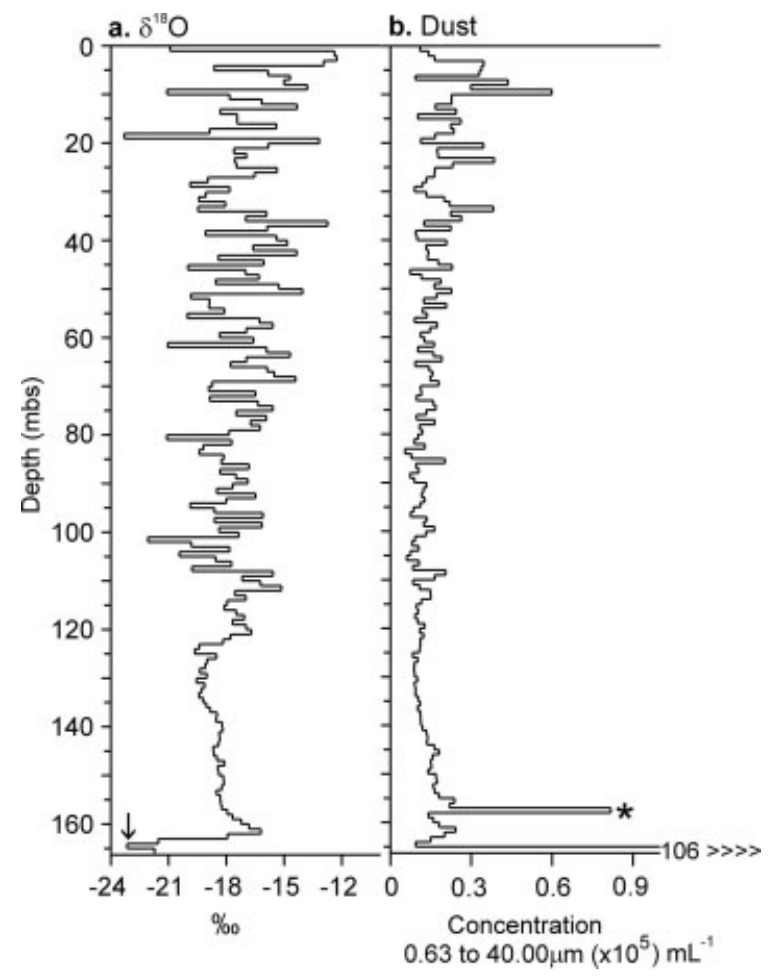

Fig. 2. One-meter averages of (a) $\delta^{18} \mathrm{O}(\%)$ and (b) dust concentrations $(0.63-40.0 \mu \mathrm{m}$ diameters $)\left(\times 10^{5} \mathrm{~mL}^{-1}\right)$ from Huascarán core 2. The arrow in (a) and the asterisk in (b) indicate features discussed in the text.

$1.4 \mathrm{~m}$ ice equivalent (Henderson, 1996), the upper portion of the core could be sampled at sub-annual resolution. The dating for this section was determined by counting the peaks in dust, nitrate and $\delta^{18} \mathrm{O}$ that formed every dry season during the austral winter from June to September (Thompson and others, 1995). Thus the annual averages of the measured parameters were calculated based on thermal years (dry season to dry season). However, below AD 1817 (119.26 mbs) the thinning of the annual layers from vertical flow was such that seasonal resolution of the parameters was difficult to maintain. However, annual dating was still possible down to $125.2 \mathrm{mbs}$ (corresponding to the $1719 / 20$ thermal year).

The original Holocene timescale for the Huascarán ice core (Thompson and others, 1995) was constructed using an empirical two-parameter model (Bolzan, 1985; Reeh, 1988), as shown in Figure 3a. The rate of thinning with depth ( $p$ in the model equation in Fig. 3a) was first calculated for the top of the core where the timescale was annually resolvable, using the dates of 1915 (78 years before 1993) at $86.47 \mathrm{mbs}$ and 1817 (176years before 1993) at $119.26 \mathrm{mbs}$ as pinning points, and assuming steady-state conditions with a constant accumulation of $1.74 \mathrm{~m}$ ice equivalent ( $b$ in the equation). The lower $47 \mathrm{~m}$ of the core (119.26-166.07 mbs) were dated by constraining the ${ }^{18} \mathrm{O}$ depletion at $164.1 \mathrm{mbs}$ (marked by an arrow in Fig. 2a) as the Younger Dryas (YD) event. This was ascertained by matching the lowest $3 \mathrm{~m}$ of the ice core with the calibrated ${ }^{14} \mathrm{C}$ dated record of $\delta^{18} \mathrm{O}$ of $G$. bulloides from the deep-sea marine core SU81-18, which was drilled in the tropical North Atlantic off the coast of Portugal (Bard and others, 1987; Fairbanks, 1989). The midpoint of the YD event in the Huascarán record was assigned an age of $12.25 \mathrm{kyr}$ BP, consistent with the YD age in the layer-counted 

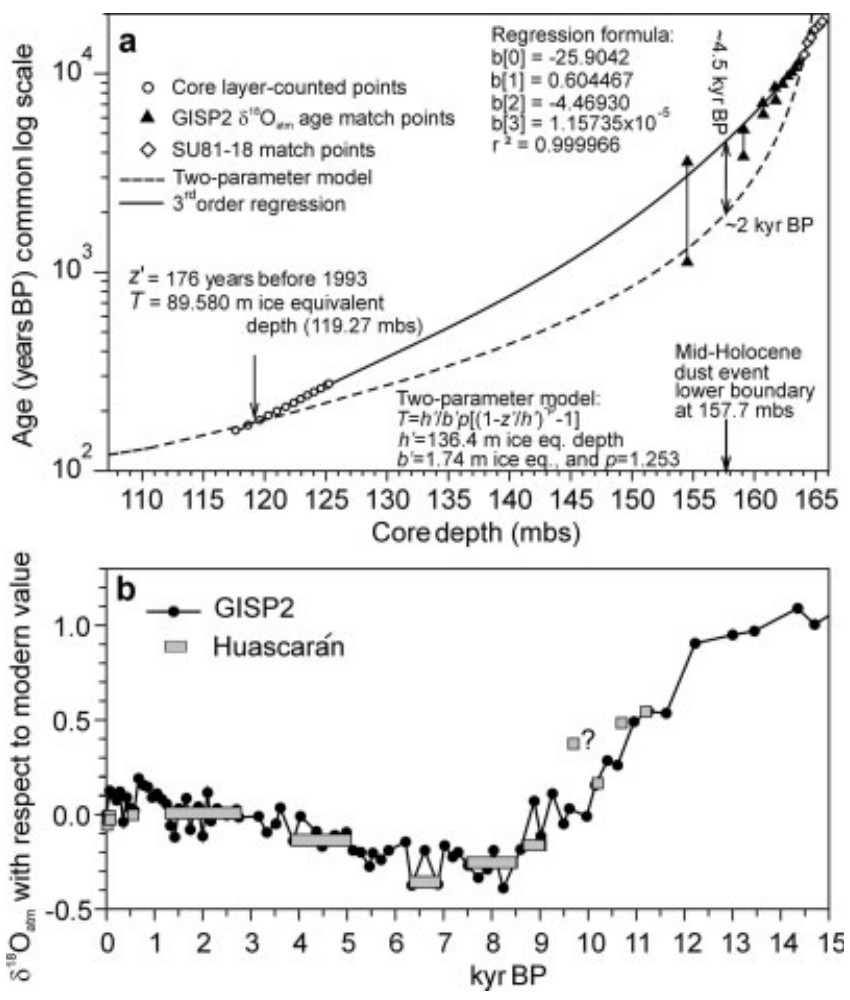

Fig. 3. (a) Timescale development for Huascarán core 2. The earlier timescale, which was developed for Thompson and others (1995) and is depicted by the dashed line, was calculated using the twoparameter model formula, with $h$ (total length of the core in ice equivalent $)=136.40 \mathrm{~m}, b$ (modern accumulation in ice equivalent) $=1.74 \mathrm{~m}, p$ (thinning parameter calculated from this model for the top of the core where layer counting was possible) $=1.253$. In addition, $z$ is depth in the core, and $T$ is its corresponding age in years BP. The revised timescale is depicted by the solid line, and is discussed in the text. The SU81-18 match points were derived from matching the $\delta^{18} \mathrm{O}$ from the lowest $3 \mathrm{~m}$ of the Huascarán core (i.e. the LGS) with the $\delta^{18} \mathrm{O}$ from a tropical North Atlantic marine core. (b) Matching between $\delta^{18} \mathrm{O}_{\text {atm }}$ in the GISP2 ice core and the Huascarán ice core. GISP2 data can be downloaded from ftp:// ftp.ncdc.noaa.gov/pub/data/paleo/icecore/greenland/summit/gisp2/ gases/gas.txt.

GRIP and GISP2 (Greenland) ice-core records (Johnsen and others, 1992; Taylor and others, 1993). With this lower chronological horizon established, the Holocene part of the Huascarán record was calculated with the two-parameter model using the thinning rate $(p=1.253)$ that was determined for the upper $119 \mathrm{~m}$ of the core (Fig. 3a). In this chronology, the large Holocene dust event at $157.7 \mathrm{mbs}$ (shown by the asterisk in Fig. 2b) was calculated at $\sim 2 \mathrm{kyr}$ BP.

Since the LGS portion of the Huascarán record was matched with an absolutely dated marine core, the confidence in the chronology of that part of the record was reasonable. However, the confidence in the Holocene dating was lower because of the lack of chronological calibration between AD 1817 and 12.25 kyr BP. Several years later, the Holocene timescale was revised using the analyses of the isotopic composition of $\mathrm{O}_{2}$ in the air trapped in glacier ice bubbles $\left(\delta^{18} \mathrm{O}_{\text {air }}\right)$, which were measured by T. Sowers at Pennsylvania State University. Sowers and others (1989) demonstrated that $\delta^{18} \mathrm{O}_{\text {air }}$ reflects changes in the global atmosphere. Since the inter-hemispheric mixing time is only $\sim 1$ year, the $\delta^{18} \mathrm{O}_{\text {air }}$ is constant throughout the atmosphere at any time, even though the turnover period is $\sim 1200$ years (Bender and others, 1994b). The glacial/interglacial transition $(\sim 8.0-15.0 \mathrm{kyr} B \mathrm{PP})$ is characterized by large, virtually simultaneous changes in $\delta^{18} \mathrm{O}_{\text {air }}$ in Greenland and Antarctic cores that are dated by independent methods (Sowers and Bender, 1995), with an estimated error of $\sim 600$ years in the age-depth relationships. When the ages derived from these $\delta^{18} \mathrm{O}_{\text {air }}$ measurements (Bender and others, 1994a) were correlated with the $\delta^{18} \mathrm{O}_{\text {air }}$ data from samples from the Huascarán ice core (Fig. 3b), the range of error for the tropical core was construed as being similar to the polar records over this transition. The measurements of the Huascarán $\delta^{18} \mathrm{O}_{\text {air }}$ provided several time horizons for the Early Holocene that allowed for the development of a new age-depth relationship for the entire Holocene by passing a third-order regression curve through the chronological horizons from the layer-counted points at the top to the $\delta^{18} \mathrm{O}_{\text {atm }}$ match points towards the bottom (Fig 3a). The match points above $9 \mathrm{kyr} B \mathrm{P}$ were not used to calculate the regression because they covered too large a range of possible corresponding dates in the Greenland record (Fig. 3b), but they are plotted on the regression curve as a confirmation of the accuracy of the age-depth relationship. An error of $\sim 5$ years was estimated around the upper pinning point of the model (AD 1720), and the range increased to $\sim 600$ years at $\sim 8 \mathrm{kyr} B \mathrm{P}$, as determined by the transfer of the $\delta^{18} \mathrm{O}_{\text {air }}$-based timescale over the glacial/ interglacial transition as discussed above. The original and the revised age-depth relationships are compared in Figure 3a. The new chronology for the Huascarán record moved the lower (earlier) boundary of the large Holocene dust peak (hereafter referred to as the MHDE, or the Middle Holocene dust event) from its originally reconstructed date at 2 kyr BP to $4.5 \mathrm{kyr} B \mathrm{P}$.

\section{THE MIDDLE HOLOCENE DUST EVENT}

The dust and $\delta^{18} \mathrm{O}$ data for the entire $19 \mathrm{kyr}$ Huascarán icecore record, which are recalculated according to the revised timescale, are illustrated in Figure $4 a$ and b, respectively, as 100 year averages. Other than the very high dust concentration levels of the LGS (prior to $17 \mathrm{kyr} B P$ ), the MHDE is the most prominent feature of the dust record. During this time, the $\delta^{18} \mathrm{O}$ was decreasing from its high postglacial levels at $\sim 10 \mathrm{kyr}$ BP. The moisture source for the eastern Peruvian Andes and for the northern Amazon Basin ultimately is the tropical North Atlantic, from where the water vapor is carried by northeasterly trade winds over the ocean, then recycled over the Amazon forest (Grootes and others, 1989; Thompson and others, 1995). The $\delta^{18} \mathrm{O}$ curve over the last 10 kyr resembles the tropical Northern Hemisphere insolation curve through the Holocene (Berger and Loutre, 1991), and both the $\delta^{18} \mathrm{O}$ and the sea surface temperatures (SSTs) of the source region may be reflections of the insolation variations.

The MHDE is prominent in Figure $4 b$, and detailed (i.e. every sample) views of the dust concentrations and size distributions between 3.7 and $5.0 \mathrm{kyrBP}$ are shown in Figure $4 \mathrm{c}-\mathrm{h}$. In addition to the high concentration (Fig. 4c), the sizes of the mineral dust in the MHDE also demonstrate that this is a unique feature in the Huascarán Holocene record. Submicron particles (Fig. 4d) constitute up to $70 \%$ of the total concentration between 0.63 and $40 \mu \mathrm{m}$ in diameter, which is $30-40 \%$ higher than pre- and 
post-MHDE levels (Fig. 4e). However, the size fraction $>5 \mu \mathrm{m}$ also increases during this event (Fig. 4f), and even the concentration of giant particles $(>16 \mu \mathrm{m})$ ranges over an order of magnitude higher (Fig. 4g), although the per cent of this size range is reduced from $3 \%$ of the total concentration in the pre- and post-event levels to $1 \%$ within the peak (Fig. 4h). The concentrations of the particles $>5.0 \mu \mathrm{m}$ actually increase $\sim 100$ years before the increase in submicron dust, and remain high for several decades after the fine-dust levels abruptly drop.

\section{CLIMATIC AND ENVIRONMENTAL CONDITIONS DURING THE MIDDLE HOLOCENE}

There is a large collection of Holocene proxy climate records from the Andes, the Altiplano and the Amazon Basin that demonstrate that an arid period occurred during the time of the MHDE in the Huascarán ice-core record. Stableisotope analyses of planktonic foraminifera from the Amazon fan show that one of highest ${ }^{18} \mathrm{O}$ values in the Holocene (inferring reduced Amazon River flow) occurred $\sim 4.5$ kyr BP (Maslin and Burns, 2000), almost contemporaneously with a depletion of ${ }^{18} \mathrm{O}$ in the isotopic record from Lake Junín, Peru (Seltzer and others, 2000). Evidence for Middle Holocene aridity on the Altiplano comes from Lake Titicaca on the border between Peru and Bolivia, where the per cent of fresh-water plankton reached its lowest levels between $\sim 5$ and $2 \mathrm{kyr} B \mathrm{P}$, and the per cent saline diatoms increased at $\sim 6 \mathrm{kyr} B \mathrm{PP}\left({ }^{14} \mathrm{C}\right.$ age $)$ and reached a maximum at 3.6-4.0 kyr BP $\left({ }^{14} \mathrm{C}\right.$ age) (Baker and others, 2001). Tapia and others (2003) offer a more refined timeline for climate variation in this interval using the Lake Titicaca record of per cent saline planktonic taxa, which confirms that although water levels were low between 3 and $6 \mathrm{kyr} B \mathrm{~B}$, the lowest levels were achieved at $\sim 4.5 \mathrm{kyr} B$.

The significant increase in very large dust particles in the MHDE in the Huascarán core is suggestive of aridity in the Cordillera Blanca. A drier climate may have resulted in decreasing snowfall which could not keep pace with sublimation during the dry season, leading to ice recession on the peaks. There is no evidence in the Huascarán climate record (in the stable isotopes or in the visible stratigraphy), nor in any nearby climate record, that an anomalous warming occurred during this time.

The MHDE is noteworthy not only because it is a unique feature in the Huascarán Holocene record, but also because it appeared during a time when a global-scale climatic disruption affected a large region from North Africa through the Mediterranean area, to as far east as China. The paleoclimatic, archeological and historical records previously listed indicate that during the third millennium BCE (before the Common Era) a sudden and severe event, which was probably a protracted drought, occurred in many regions that had been under the expanded influence of the Asian/Indian/African monsoon during the first half of the Holocene. This drought was contemporaneous with the decline of the Akkadian Empire in Mesopotamia (Weiss and others, 1993), the failure of Nile River floods that were coincident with the decline of North African civilizations (Hassan, 1997) and the end of the Harappan civilization in the Indus valley (Staubwasser and others, 2003). Whether the drought was actually instrumental in the collapse of these societies is a controversial point among archeologists (e.g. Butzer, 1997), but the evidence is very strong that this

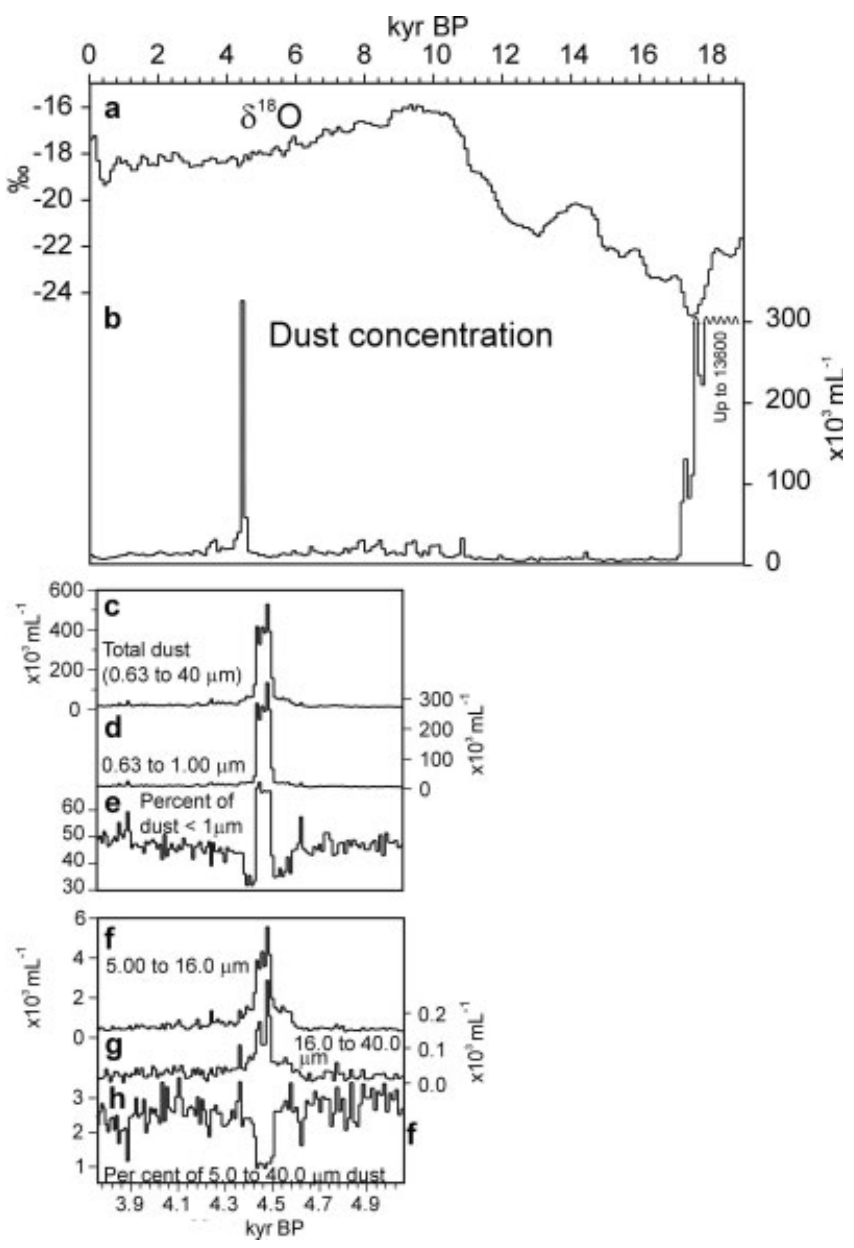

Fig. 4. (a, b) Huascarán core $2 \delta^{18} \mathrm{O}$ (a) and dust concentration (b) records for the last $19 \mathrm{kyr}$, shown as 100 year averages. The MHDE is prominent and in $(\mathrm{c}-\mathrm{h})$ the data are shown as actual samples (average length $\sim 2 \mathrm{~cm}$ ). (c) Total dust concentrations from 0.63 to $40 \mu \mathrm{m}$; (d) the concentration of submicron dust; (e) the per cent of submicron dust with respect to total dust; $(\mathrm{f}-\mathrm{h})$ concentrations of large $(5-16 \mu \mathrm{m})(\mathrm{f})$ and giant ( $>16$ to $40 \mu \mathrm{m})$ particles (g) through the $\mathrm{MDHE}$, and the per cent of large particles with respect to total dust (h).

climatic anomaly occurred at or near the same point in time as these historical events.

Figure 5 shows some of the geological records that document this Middle Holocene aridity, in addition to the Huascarán dust profile. A marine core from the Gulf of Oman (Cullen and others, 2000) contains an abrupt spike in carbonates (Fig. 5a) which have been chemically traced to an archeological site (Tell Leilan) in Syria, the home of the Akkadian culture (Weiss and others, 1993). The shape of this profile is similar to that from Huascarán (Fig. 5b), which shows a sudden onset and then a more gradual decline followed by a secondary peak. An ice-core record from Kilimanjaro, Tanzania, (Thompson and others, 2002) contains an unusually thick, black dust band that is dated around $4.0 \mathrm{kyr} \mathrm{BP}$ (Fig. 5c), and is indicative of a period that may have lasted several decades to centuries during which the Northern Ice Field, presently the largest on the mountain, had dramatically reduced in size. Lake records from equatorial and North Africa (Gasse, 2000) (Fig. 5d-f) indicate that water levels had decreased greatly, as did lake levels from western Tibet (Gasse and others, 1991, 1996), which are not shown. 


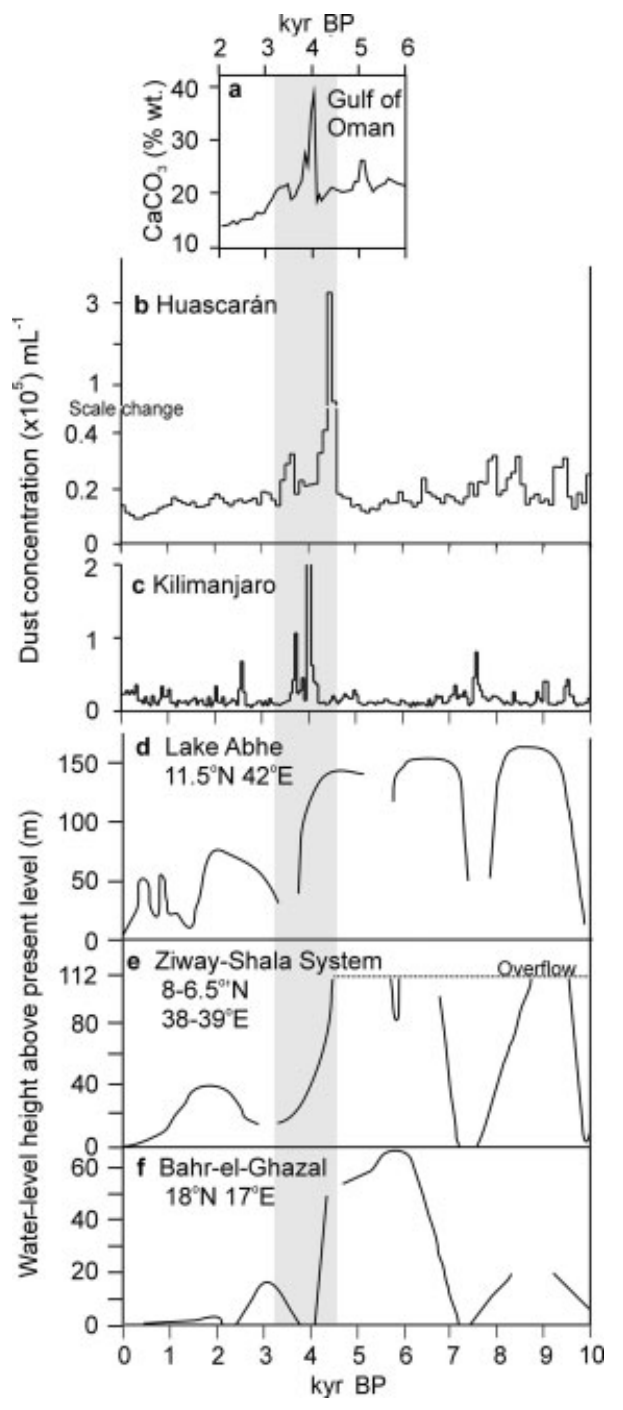

Fig. 5. Comparisons of (a) the Gulf of Oman Middle Holocene carbonate record on a calibrated ${ }^{14} \mathrm{C}$ timescale (modified from Cullen and others, 2000); (b) the Huascarán Holocene dust record; (c) the dust from the Kilimanjaro ice core (modified from Thompson and others, 2002); and (d-f) tropical African Holocene lake level records (modified from Gasse, 2000) from Lake Abhe (Gasse, 1977) (d), Ziway-Shala system (Gillespie and others, 1983) (e) and Bahrel-Ghazal (Servant and Servant-Vildary, 1980) (f). The grey bar marks the Middle Holocene arid period in the records.

Other records not shown in Figure 5 also contain evidence of a sudden and marked arid-climate episode at this time. A speleothem from the Soreq cave in Israel (BarMatthews and others, 1999) shows an abrupt drop in $\delta^{13} \mathrm{C}$, implying that lower precipitation occurred within the 4.24.5 kyr BP window. Palynological data from north-central China suggest a cold, dry period from 3.95 to $4.45 \mathrm{kyr} B \mathrm{P}$, which is inferred from a sudden decrease in tree pollen concentration (Xiao and others, 2004). Morrill and others (2003) compiled paleoclimatic data from monsoon Asia, particularly China, to produce a pattern of abrupt midHolocene monsoon failure in this region.

The discrepancy in timing between the onset of the MHDE in Huascarán and the carbonate peak in the Gulf of Oman core (4.5 kyr BP vs $4.2 \mathrm{kyr} B \mathrm{~B}$, respectively) may be the result of the different techniques used to develop the timescales for the two records. The marine record was dated with the aid of ${ }^{14} \mathrm{C}$ dates from carbonates, whereas the
Holocene timescale for the ice core was based on flow modeling and curve matching, using $\delta^{18} \mathrm{O}_{\text {air }}$ match points with well-dated polar cores as previously described. This allowed for the revised age of the MHDE, but with a range of uncertainty between 5 years and 600 years. In fact, of all the records shown in Figure 5, Huascarán is the only one with a timescale that was not developed using calibrated ${ }^{14} \mathrm{C}$ dates. Despite timing differences, the dust event has the same general shape in the high-resolution records from Huascarán, the Gulf of Oman and Kilimanjaro, i.e. a large, abrupt dust increase, then a more gradual decrease, followed by a smaller, secondary peak. It is interesting that the character of a climatic event should be so similar in records that come from sites located in different environments on opposite sides of the Earth. If these records are recording the same event, by what physical processes are they linked?

\section{THE MODERN LINKS BETWEEN THE MHDE IN HUASCARÁN AND DROUGHT IN THE TROPICAL EASTERN HEMISPHERE}

During the austral summer (December-March), which is the wet season in the Southern Hemisphere tropics, the InterTropical Convergence Zone is at its southernmost position and the northeasterly trade winds move across the equatorial Atlantic from west Africa to northeastern South America. The dust that is entrained off the west coast of Africa by frequent windstorms is caught up by the trade winds, which are connected to the southern limb of the subtropical Azores high-pressure system, which in turn is the southern dipole of the North Atlantic Oscillation (NAO). Moulin and others (1997) statistically linked the transport of dust from the west African coast to the strength of the NAO. Much of the dust is blown back towards the northeast by the clockwise motion of the subtropical high, but a smaller amount is carried with the moisture across the tropical North Atlantic, and in fact Saharan dust which has been transported during the austral summer has been found in the Amazon Basin (Swap and others, 1992).

Since the source of Huascarán's precipitation is likely the tropical Atlantic, it is probable that some of the dust that originates in North Africa is carried by the moist air masses across the Amazon Basin to the Cordillera Blanca and wetdeposited on glaciers there (Davis, 2002). The recent atmospheric processes that facilitate the movement of dust between the desert regions of North Africa and tropical South America are illustrated in Figure 6, which shows correlation fields between the wet-season dust concentrations in the Huascarán core and $5^{\circ} \times 5^{\circ}$ grids of US National Centers for Environmental Prediction/US National Center for Atmospheric Research (NCEP/NCAR) re-analysis data (Kalnay and others, 1996) from December to March of global mean sea-level pressure (SLP; Fig. 6a) and global 850 mbar zonal winds (Fig. 6b) from 1949 to 1992, the last full year of the ice-core record. High SLP is associated with dry conditions, so the significant two-tailed Pearson correlations $(R>0.3$, significant at the 0.05 level) between SLP in the Sahara, the Sahel, the Bodélé region of northcentral Africa (Fig. 6a) and ice-core dust concentration suggest that aridity here may provide a potent potential source region for the dust that eventually finds its way to the Cordillera Blanca. Furthermore, the significant negative correlations $(R<-0.3$, significant at the 0.05 level) between 
the dust and lower-level easterly winds from North Africa to the eastern coast of South America (Fig. 6b) indicate that zonal wind velocities from the potential source tend to be higher during high-dust years. The correlation field is negative because easterly winds are recorded in the NCEP/ NCAR database as negative values (Fig. 6c). This relationship ends just inside the northeast coast of Brazil, perhaps because the relatively 'linear' trade-wind circulation over the ocean is disrupted by moisture recycling and convective activity over the Amazon rainforest.

Other regions of significant correlation are also observed in Figure $6 a$, such as the negative relationship between Huascarán dust and SLP in the far North Atlantic (in the region of the Icelandic low). When this is viewed in conjunction with the significant $+R$ field over North Africa, the Mediterranean and the tropical Atlantic, it contributes to the evidence that austral summers of high dust concentration are coincident with boreal winters with positive NAO indices. In addition, the SLP grid in the tropical western Pacific shows positive significant correlations with the dust concentrations, indicating negative Southern Oscillation Indices (SOI), which are symptomatic of El Niño conditions.

Thus, the easterly circulation across the tropical Atlantic that is influenced by the subtropical node of the NAO appears to be the link between the mineral dust in the Huascarán glacier and the climate in North Africa and the Middle East. However, the interplay between the strength and phase of the NAO and the circulation of the African/ Asian monsoon is connected with the climate of this potential source region for Huascarán dust. Today during winters of high NAO indices, the Icelandic low and the Azores high intensify and move northward, causing the westerly storm tracks to shift from the Mediterranean region and North Africa to northern Europe (Fig. 6b). For example, low winter discharge from the Tigris and Euphrates Rivers is significantly correlated with the positive phase of the NAO (Cullen and deMenocal, 2000). Not only does this result in a drier climate in southern Eurasia and southwest Asia, but the vigorous northeasterly trade-wind circulation from the Azores high transports more available dust across the Atlantic to South America. Positive NAO is also associated with a more intense Middle Eastern Jet Stream (MEJS) (Yang and others, 2004), which is an antecedent signal for a weaker Asian monsoon. When the MEJS is strong in the winter, an ENSO-type warming appears in the equatorial eastern Pacific (NINO3). Historically, increases in the NINO3 SSTs have been significantly correlated with Asian/ Indian monsoon failure, although the correlation has weakened in recent decades (Kumar and others, 1999). The development of ENSO conditions during years of positive NAO is also indicated in Figure 6, which shows atmospheric circulation patterns indicative of negative SOI. These observations are qualitative, since currently there is no statistically significant year-to-year link that has been noted between ENSO and NAO, although over decadal timescales there does appear to be a relationship between NAO and the ENSO-linked Pacific Decadal Oscillation (PDO) (Readinger, 2003).

Possible teleconnections have been proposed between the North Atlantic and the African/Asian monsoons during the last glacial (Overpeck and others, 1996; Schulz and others, 1998), during the glacial/Holocene transition (Sirocko and others, 1996) and during the Holocene (Gupta and others, 2003; Wang and others, 2005). Stated simply,

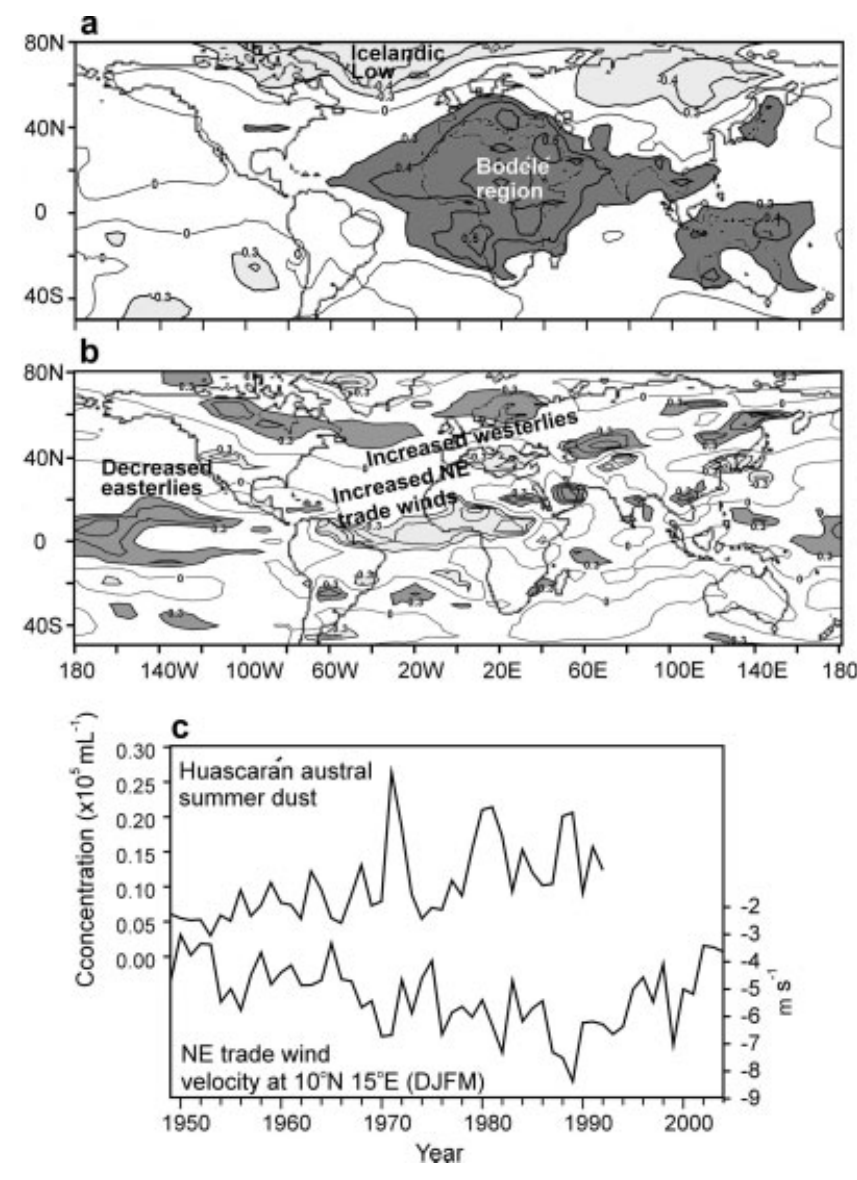

Fig. 6. Significant correlation fields $(-0.3>R>+0.3$, significant at the 0.05 level) between Huascarán wet-season (austral summer) dust concentration and NCEP/NCAR re-analysis data (DecemberMarch) for (a) SLP and (b) zonal wind velocity from 1949 to 1992. Dark/light shading depicts fields of significant positive/negative correlations. The correlation grids are $5^{\circ}$ by $5^{\circ}$. (c) A comparison between the wet-season dust concentrations from 1949 to 1992 and the easterly wind velocities in the region of highest correlation in north-central Africa illustrates why $R$ is negative in the latitudes dominated by easterlies.

monsoon failures were contemporaneous with North Atlantic cooling (associated with arctic ice discharge), which in turn contributed to strengthened westerlies across Eurasia. Comparisons between marine records from the Arabian Sea and the North Atlantic show that these conditions existed several times during the Holocene, and one of the later episodes occurred between 4.0 and 4.5 kyr BP (Gupta and others, 2003).

The MHDE therefore may have been connected to a protracted interval of ENSO-linked African/Asian monsoon weakening, which was coupled with strengthening of the Icelandic low and Azores high. Cooling of the North Atlantic accompanied an ice discharge event, and contributed to more intense westerlies across northern Eurasia. Currently, ENSO events are also linked to aridity in the Cordillera Blanca, and if this was the case in the Middle Holocene, ice recession on the Huascarán peaks (which resulted in the influx of large particles onto the col) may also have been controlled by these conditions. Because the concentrations of large dust particles in the MHDE increased before the influx of the submicron particles, the ENSO conditions responsible for aridity in the northeast Andes may have 


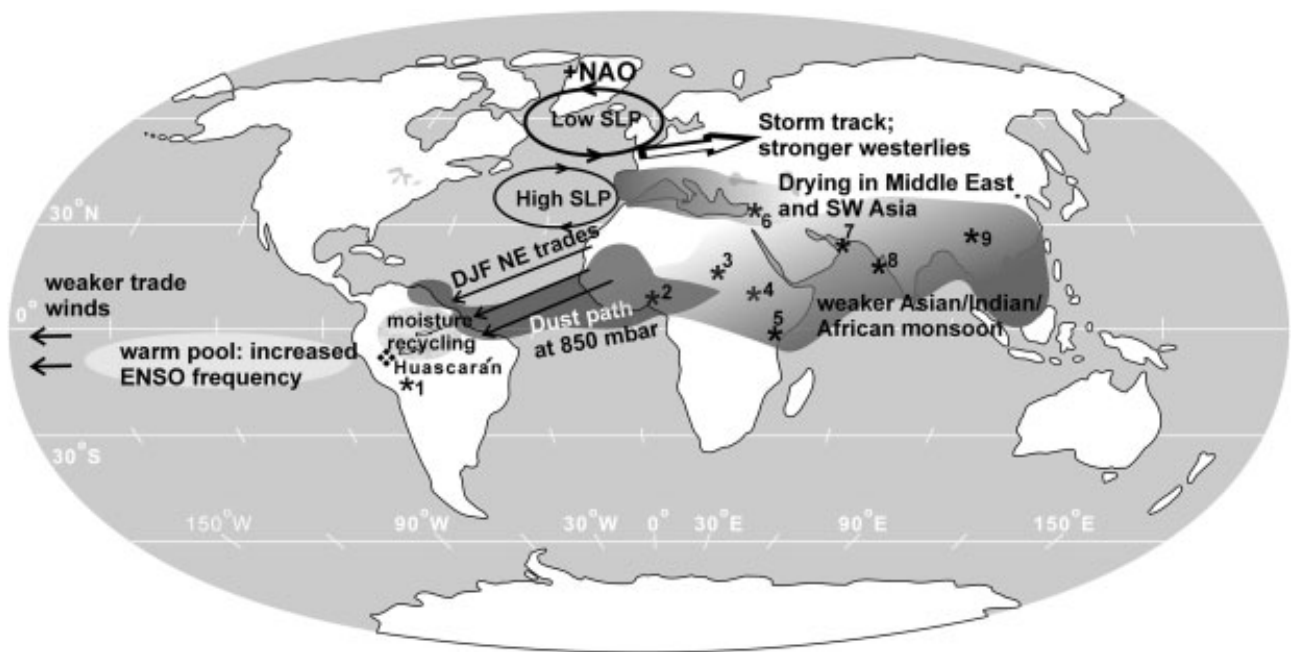

Fig. 7. Schematic illustrating global-scale mechanisms mentioned in the text that may have been influential in the Middle Holocene aridity and its appearance in the Huascarán ice core. Other sites where the event is documented in climate records are numbered: 1 . Lake Titicaca (Tapia and others, 2003); 2. Bahr-el-Ghazal (Servant and Servant-Vildary, 1980); 3. Lake Abhe (Gasse, 1977); 4. Ziway-Shala system (Gillespie and others, 1983); 5. Kilimanjaro (Thompson and others, 2002); 6. Soreq cave (Bar-Matthews and others, 1999); 7. Gulf of Oman (Cullen and others, 2000); 8. Indus delta (Staubwasser and others, 2003); and 9. Dongge cave (Wang and others, 2005). DJF: DecemberFebruary.

preceded the monsoon weakening. In fact, the timing of the interval of lake desiccation in tropical South America suggests that it may have predated and postdated the Eastern Hemisphere drought. The major elements of this nearglobal-scale mechanism are illustrated in Figure 7, along with the locations of some of the sites from where records of this abrupt and prolonged aridity have been obtained.

\section{CONCLUSIONS}

The MHDE may have been the product of a protracted series of ENSO events that possibly were associated with widespread monsoon failures, which in turn may have been linked with North Atlantic regional cooling and strengthened westerlies over Eurasia. The appearance of abrupt climatic disruptions in such distant locations as the tropical Andes, North Africa, the Middle East, southwest to east Asia and the North Atlantic suggests strong linkages between high- and low-latitude atmospheric processes. The questions that remain to be addressed concern: (1) the underlying cause for this near-global-scale episode, and (2) which processes, i.e. those in the tropics (ENSO, monsoon circulation) or those in the North Atlantic (ice rafting, ocean cooling), might have been the triggers. The ultimate forcing for abrupt climate change on orbital timescales is thought to be non-linear responses (through oceanic, vegetative and possibly cryospheric feedbacks) to linear insolation changes (Ganopolski and others, 1998; deMenocal and others, 2000). In fact, a series of feedbacks between the low latitudes and the arctic region may have sustained the Middle Holocene drought in the tropics over several hundred years.

\section{ACKNOWLEDGEMENTS}

We gratefully acknowledge the participants in the 1993 Huascarán drilling expedition, B. Koci, V. Mikhalenko, G. Seltzer, P. Kinder and Pin-Nan Lin, and the Peruvian mountaineers F. Vicencio Maguina, M. Camones Gonzales and M. Henostroga Zambrano. We also thank Pin-Nan Lin for the $\delta^{18} \mathrm{O}$ analysis, and $\mathrm{K}$. Henderson whose efforts to reconstruct the Huascarán timescale were invaluable. The Huascarán program was funded by the US National Oceanic and Atmospheric Administration. The comments of $U$. Ruth and an anonymous reviewer greatly helped to improve this paper and are very much appreciated. This is Byrd Polar Research Center contribution No. 1322.

\section{REFERENCES}

Baker, P.A. and 8 others. 2001. The history of South American tropical precipitation for the past 25,000 years. Science, 291(5504), 640-643.

Bar-Matthews, M., A. Ayalon, A. Kaufman and G.J. Wasserburg. 1999. The eastern Mediterranean palaeoclimate as a reflection of regional events: Soreq cave, Israel. Earth Planet Sci. Lett., 166, 85-95.

Bard, E., M. Arnold, P. Maurice, J. Duprat, J. Moyes and J.C. Duplessy. 1987. Retreat velocity of the North Atlantic polar front during the last deglaciation determined by ${ }^{14} \mathrm{C}$ accelerator mass spectrometry. Nature, 328, 791-794.

Bender, M. and 6 others. 1994a. Climate correlations between Greenland and Antarctica during the past 100,000 years. Nature, 372(6507), 663-666.

Bender, M., T.A. Sowers and L. Labeyrie. 1994b. The Dole effect and its variations during the last 130,000 years as measured in the Vostok ice core. Global Biogeochem. Cy., 8(3), 363-376.

Berger, A. and M.F. Loutre. 1991. Insolation values for the climate of the last 10 million years. Quat. Sci. Rev., 10, 297-318.

Bolzan, J.F. 1985. Ice flow at the Dome C ice divide based on a deep temperature profile. J. Geophys. Res., 90(D5), 8111-8124.

Butzer, K.W. 1997. Sociopolitical discontinuity in the Near East c. 2200 BCE: scenarios from Palestine and Egypt. In Dalfes, H.N., G. Kukla and H. Weiss, eds. Third millennium BC climate change and Old World collapse. Berlin, etc., Springer, 245-296. (NATO ASI Series 1.)

Cullen, H.M. and P.B. deMenocal. 2000. North Atlantic influence on Tigris-Euphrates streamflow. Int. J. Climatol., 20(8), 853-863.

Cullen, H.M., P.B. deMenocal, S. Hemming and G. Hemming. 2000. Climate change and the collapse of the Akkadian empire: evidence from the deep sea. Geology, 28(4), 379-382. 
Davis, M.E. 2002. Climatic interpretations of eolian dust records from low-latitude, high-altitude ice cores. (PhD thesis, Ohio State University.)

deMenocal, P. and 6 others. 2000. Abrupt onset and termination of the African humid period: rapid climate responses to gradual insolation forcing. Quat. Sci. Rev., 19, 347-361.

Fairbanks, R.G. 1989. A 17,000-year glacio-eustatic sea level record: influence of glacial melting rates on the Younger Dryas event and deep-ocean circulation. Nature, 342(6250), 637-642.

Ganopolski, A., C. Kubatzki, M. Claussen, V. Brovkin and V. Petoukhov. 1998. The influence of vegetation-atmosphereocean interaction on climate during the mid-Holocene. Science, 280, 1916-1919.

Gasse, F. 1977. Evolution of Lake Abhé (Ethiopia and T.F.A.I.) from 70,000 B.P. Nature, 265, 42-45.

Gasse, F. 2000. Hydrological changes in the African tropics since the Last Glacial Maximum. Quat. Sci. Rev., 19(1-5), 189-211.

Gasse, F. and 12 others. 1991. A 13,000-year climate record from western Tibet. Nature, 353, 742-745.

Gasse, F., J.C. Fontes, E. van Campo and K. Wei. 1996. Holocene environmental changes in Bangong Co basin (Western Tibet). Part 4: Discussion and conclusions. Palaeogeogr., Palaeoclimatol., Palaeoecol., 120(1), 79-92.

Gillespie, R., F.A. Street-Perrott and R. Switsur. 1983. Post-glacial arid episodes in Ethiopia have implications for climate prediction. Nature, 306, 680-683.

Grootes, P.M., M. Stuiver, L.G. Thompson and E. MosleyThompson. 1989. Oxygen isotope changes in tropical ice, Quelccaya, Peru. J. Geophys. Res., 94(D1), 1187-1194.

Gupta, A.K., D.M. Anderson and J.T. Overpeck. 2003. Abrupt changes in the Asian southwest monsoon during the Holocene and their links to the North Atlantic Ocean. Nature, 421(6921), 354-357.

Hassan, F.A. 1997. Nile floods and political disorder in early Egypt. In Dalfes, H.N., G. Kukla and H. Weiss, eds. Third millennium $B C$ climate change and Old World collapse. New York, Springer, 1-24. (NATO ASI Series 1.)

Henderson, K.A. 1996. The El Niño-Southern Oscillation and other modes of tropical climate variability as recorded in ice cores from the Nevado Huascarán Col, Peru. (MS thesis, Ohio State University.)

Johnsen, S.J. and 9 others. 1992. Irregular glacial interstadials recorded in a new Greenland ice core. Nature, 359(6393), 311-313

Kalnay, E. and 21 others. 1996. The NCEP/NCAR 40-year reanalysis project. Bull. Am. Meteorol. Soc., 77(3), 437-471.

Kumar, K.K., B. Rajagopalan and M.A. Cane. 1999. On the weakening relationship between the Indian monsoon and ENSO. Science, 284(5423), 2156-2159.

Maslin, M.A. and S.J. Burns. 2000. Reconstruction of the Amazon Basin effective moisture availability over the past 14,000 years. Science, 290(5550), 2285-2287.

Morrill, C., J.T. Overpeck and J.E. Cole. 2003. A synthesis of abrupt changes in the Asian summer monsoon since the last deglaciation. Holocene, 13(4), 465-476.

Moulin, C., C.E. Lambert, F. Dulac and U. Dayan. 1997. Control of atmospheric export of dust from North Africa by the North Atlantic Oscillation. Nature, 387(6634), 691-694.

Overpeck, J.T., D.M. Anderson, S. Trumbore and W.L. Prell. 1996. The southwest Indian monsoon over the last 18,000 years. Climate Dyn., 12(3), 213-225.

Readinger, C.R. 2003. The North Atlantic and Pacific decadal oscillations and their imprint on Greenland's climate record. (MS thesis, Ohio State University.)
Reeh, N. 1988. A flow-line model for calculating the surface profile and the velocity, strain-rate, and stress fields in an ice sheet. J. Glaciol., 34(116), 46-54.

Schulz, H., U. Rad and H. Erlenkeuser. 1998. Correlation between Arabian Sea and Greenland climate oscillations of the past 110,000 years. Nature, 393(6680), 54-57.

Seltzer, G.O., D. Rodbell and S. Burns. 2000. Isotopic evidence for late Quaternary climatic change in tropical South America. Geology, 28(1), 35-38.

Servant, M. and S. Servant-Vildary. 1980. L'environnement quaternaire du bassin du Tchad. In Williams, M.A.J. and H. Faure, eds. The Sahara and the Nile. Rotterdam, A.A. Balkema, 133-162.

Sirocko, F., D. Garbe-Schönberg, A. Mclntyre and B. Molfino. 1996. Teleconnections between the subtropical monsoons and high-latitude climates during the last deglaciation. Science, 272(5261), 526-529.

Sowers, T. and M. Bender. 1995. Climate records covering the last deglaciation. Science, 269(5221), 210-214.

Sowers, T., M. Bender and D. Raynaud. 1989. Elemental and isotopic composition of occluded $\mathrm{O}_{2}$ and $\mathrm{N}_{2}$ in polar ice. J. Geophys. Res., 94(D4), 5137-5150.

Staubwasser, M., F. Sirocko, P.M. Grootes and M. Segl. 2003. Climate change at the $4.2 \mathrm{ka}$ BP termination of the Indus valley civilization and Holocene south Asian monsoon variability. Geophys. Res. Lett., 30(8), 1425. (10.1029/2002GL016822.)

Swap, R., M. Garstang, M. Greco, R. Talbot and P. Kållberg. 1992. Saharan dust in the Amazon basin. Tellus, 44B(2), 133-149.

Tapia, P.M., S.C. Fritz, P.A. Baker, G.O. Seltzer and R.B. Dunbar. 2003. A late Quaternary diatom record of tropical climatic history from Lake Titicaca (Peru and Bolivia). Palaeogeogr., Palaeoclimatol., Palaeoecol., 194(1-3), 139-164.

Taylor, K.C. and 7 others. 1993. The 'flickering switch' of Late Pleistocene climate change. Nature, 361(6411), 432-436.

Thompson, L.G. 2000. Ice core evidence for climate change in the Tropics: implications for our future. Quat. Sci. Rev., 19(1-5), 19-35.

Thompson, L.G. and 7 others. 1995. Late glacial stage and Holocene tropical ice core records from Huascarán, Peru. Science, 269(5220), 46-50.

Thompson, L.G. and 11 others. 1998. A 25,000-year tropical climate history from Bolivian ice cores. Science, 282(5395), 1858-1864.

Thompson, L.G., E. Mosley-Thompson and K.A. Henderson. 2000. Ice-core palaeoclimate records in tropical South America since the Last Glacial Maximum. J. Quat. Sci., 15(4), 377-394.

Thompson, L.G. and 10 others. 2002. Kilimanjaro ice core records: evidence for Holocene climate change in tropical Africa. Science, 298(5593), 589-593.

Wang, Y. and 9 others. 2005. The Holocene Asian monsoon: links to solar changes and north Atlantic climate. Science, 308(5723), 854-857.

Weiss, H. and 6 others. 1993. The genesis and collapse of third millennium north Mesopotamian civilization. Science, 261(5124), 995-1003.

Xiao, J.L., Q. Xu, T. Nakamura, X. Yang, W. Liang and Y. Inouchi. 2004. Holocene vegetation variation in the Daihai Lake region of north-central China: a direct indication of the Asian monsoon climatic history. Quat. Sci. Rev., 23(14-15), 1513-1722.

Yang, S., K.-M. Lau, S.-H. Yoo, J.L. Kinter, K. Miyakoda and C.-H. Ho. 2004. Upstream subtropical signals preceding the Asian summer monsoon circulation. J. Climate, 17(21), 4213-4229. 